\title{
A scientific note about spectroscopic analysis of honey bee brood comb cappings in hygienic and non-hygienic honey bee colonies*
}

\author{
Michelle M. MoraIs ${ }^{1}$, Tiago M. FrancoY ${ }^{2}$, Iouri E. BorisSEVITCH ${ }^{3}$, Lionel S. GonÇALVES ${ }^{1}$ \\ ${ }^{1}$ Faculdade de Filosofia, Ciências e Letras de Ribeirão Preto - USP, Depto. Biologia, 14040-901 Ribeirão Preto, \\ SP, Brazil \\ ${ }^{2}$ Escola de Artes, Ciências e Humanidades, USP, 03828-000 São Paulo, SP, Brazil \\ ${ }^{3}$ Faculdade de Filosofia, Ciências e Letras de Ribeirão Preto - USP, Depto. Física e Matemática, \\ 14040-901 Ribeirão Preto, SP, Brazil
}

Received 25 June 2009 - Revised 23 October 2009 - Accepted 23 November 2009

spectroscopic analysis / hygienic behavior / brood cappings / Apis mellifera

Hygienic behavior (HB) involves the detection of diseased, dead, and infected larvae or pupae and their selective removal from brood cells by worker bees (Arathi et al., 2000; Arathi and Spivak, 2001). The efficiency of HB is affected by the ability of bees to recognize infected or infested brood (by chemical and physical cues). Among the various factors that have been studied that could influence the detection of cells with dead or diseased brood (Arathi et al., 2000), visual cues had not been investigated. We examined the light transmittance characteristics of the cappings of brood combs to determine if it would be possible for bees to detect abnormal brood within capped cells using visual cues.

Cell cappings from old and new brood combs (50 each) from each of three colonies of hygienic and non-hygienic bee lines were removed and tested. These previously selected hygienic colonies had a mean of $99.8 \% \mathrm{HB}$, while the non-hygienic colonies had a mean of $2.3 \% \mathrm{HB}$.

The cappings were fixed in a support device (mask) that permitted light passage only through the cappings. Initially, the intensity of the light that passed through the mask was measured without a capping. This corresponds to the incident light intensity $\left(I_{0}\right)$ that strikes the capping. Subsequently, a capping was positioned on the mask so that the transmitted light intensity $\left(I_{\text {trans }}\right)$ could be mea-

Corresponding author: M.M. Morais, mmanfrini@rge.fmrp.usp.br

* Manuscript editor: David Tarpy sured. The percent light transmittance through the cell capping was calculated as:

$$
T=\frac{I_{\text {trans }}}{I_{0}} * 100 \% \text {. }
$$

The transmittance spectra were monitored in the spectral range 400-800 nm with a BeckmannCounter U640 UV-Vis spectrophotometer.

The $I_{\text {trans }}$ is composed of the light that penetrates through the capping beeswax $\left(I_{\text {wax }}\right)$, plus the light that passes directly through the pores in the capping $\left(I_{\text {pores }}\right)$. The $I_{\text {pores }}$ can be calculated as $I_{\text {pores }}=\alpha I_{0}$, where $\alpha$ is $\alpha=\frac{P_{p}}{P_{s}}, P_{p}$ is the total pore area and $P_{s}$ is the area of the sample, respectively. The $I_{\text {wax }}$ can be calculated as $I_{w a x}=(1-\alpha) I_{0} * 10^{-A}$ (Lambert - Beer low), where $A$ is the beeswax optical absorbance, which depends on the capping thickness $L(\mathrm{~cm})$ and on the incident light wavelength $\lambda(\mathrm{nm})$, $A(\lambda)=L * A_{0}$, where $A_{0}(\lambda)$ is the absorbance of a $1 \mathrm{~cm}$ thick beeswax layer. Finally, $T$ is

$$
T(\lambda)=\left[\alpha+(1-\alpha) * 10^{-L A_{0}(\lambda)}\right] * 100 \%
$$

where $A_{0}(\lambda)$ determines the dependence of $T$ on light wavelength. These results were compared using the non parametric test "ANOVA on ranks", with the software SigmaStat 3.1.

The spectral $T$ maximum was $800 \mathrm{~nm}$ for all samples. However, even at this wavelength, $T$ did not exceed $3.5 \%$. At $543 \mathrm{~nm}$, for which bee eyes have maximum sensitivity (De Ibarra and Giurfa, 2003), $T$ was $<1 \%$. This means that less than $1 \%$ 

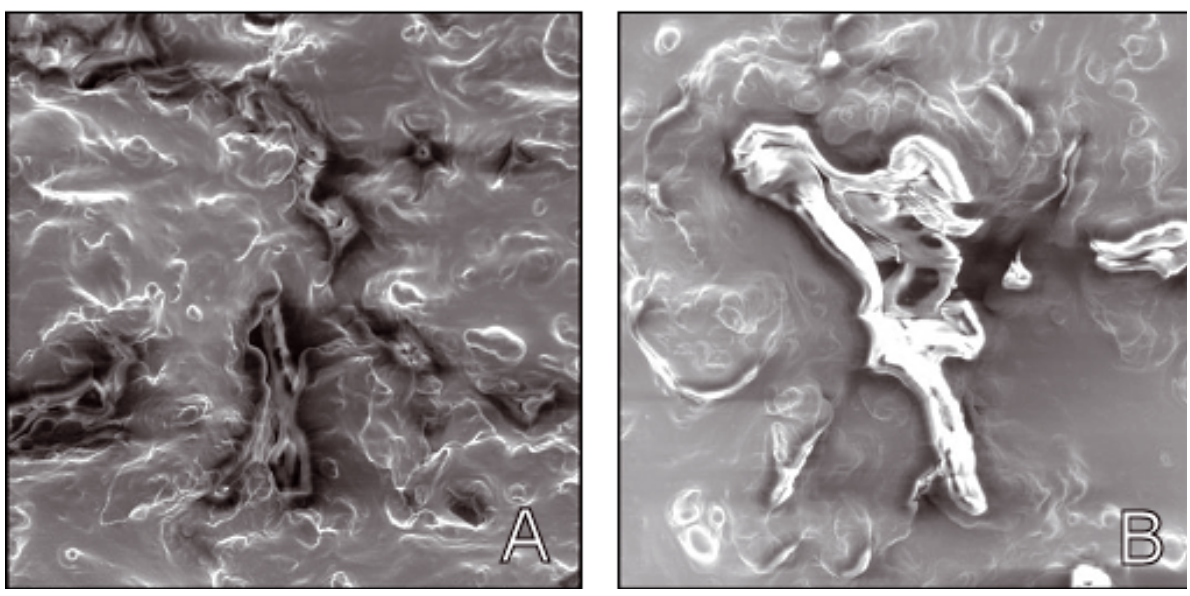

Figure 1. Scanning electron microscopy $(500 \times)$ of old comb cell cappings from (A) hygienic colonies and (B) non hygienic colonies.

of the incident light penetrated through the operculum into the cell. This light would be reflected from the pupa in the cell and return, passing once more through the capping. As a result, only about $10^{-4}$ of the incident light intensity would be available for the detection of dead or live pupae inside the cells. We conclude that visual perception by the bee for detecting sick or dead brood is unlikely. However, transmittance through wax increases in the infrared spectral range; consequently, it is possible that differences in heat levels, emitted by live or dying individuals, could be detected. Gramacho et al. (1998) demonstrated that brood cells containing dead pupae had a lower temperature than cells containing live individuals. As heat is manifested as infra-red emission, we also monitored the infra-red spectral region (above $800 \mathrm{~nm}$ ). We observed that, in this range, transmittance increased significantly. Since a live pupa is a direct source of infra-red emission (i.e., not reflected, as would incident light), this emission would need to penetrate the cell capping only once so that the reduction in intensity would be several orders of magnitude less than that of visible light.

We observed significant differences in light transmittance as a function of comb age and hygienic bee lineage. Maximum light transmittance was observed for cappings from new combs from both hygienic and non-hygienic colonies; it was $6.4 \pm 0.1 \%$ for the hygienic bees and $6.5 \pm 0.2 \%$ for the non-hygienic bees (not significantly different, $P>0.5$ ). However, transmittance was consid- erably reduced through cappings from old combs, being $2.1 \pm 0.2 \%$ for old hygienic bee combs and $5.4 \pm 0.4 \%$ for non-hygienic bee combs. This reduction in transmittance apparently is associated with increased capping thickness ( $L$; reducing the exponential factor in Eq. (1)), reduction in capping pore area (reduction of factor $\alpha$ in Eq. (1)), or both. Cell capping light transmittance for non-hygienic bee lines was 2.4 times higher than for hygienic bees. The larger pore number and size in cappings in nonhygienic colonies was confirmed by scanning electron microscopy (Fig. 1).

We conclude that visual perception for bees to detect "damaged" brood and stimulate HB is unlikely. Pores in the cell cappings could affect the efficacy of olfactory detection; however, we found the pores to be fewer and smaller in the cappings from old brood combs in hygienic colonies.

\section{ACKNOWLEDGEMENTS}

This study was supported by Capes, CNPq (Proc. 151947/2007-4) and Fapesp (Proc. 2007/07701-3). We thank Professor David De Jong for comments and for improving the final version of this manuscript.

Note scientifique sur une analyse spectroscopique des opercules de rayons de couvain d'abeilles dans les colonies avec comportement hygiénique ou non. 
Eine wissenschaftliche Notiz über die spektroskopische Untersuchung der Zelldeckel von Brutwaben in hygienischen und nichthygienischen Honigbienenvölkern.

\section{REFERENCES}

Arathi H.S., Spivak M. (2001) Influence of colony genotypic composition on the performance of hygienic behavior in the honey bee (Apis mellifera L), Anim. Behav. 62, 5766.
Arathi H.S., Burns I., Spivak M. (2000) Ethology of hygienic behaviour in the honey bee Apis mellifera L. (Hymenoptera, Apidae): Behavioural repertoire of hygienic bees, Ethology 106, 365-379.

De Ibarra N.H., Giurfa M. (2003) Discrimination of closed coloured shapes by honeybees requires only contrast to the long wavelength receptor type, Anim. Behav. 66, 903-910.

Gramacho K.P., Gonçalves L.S., Rosenkranz P. (1998) Study of temperature of brood killed by the pin-killing method in worker bees of Apis mellifera carnica, Apiacta 2, 3541. 